\title{
HUBUNGAN KEMAMPUAN BERPIKIR KREATIF DENGAN KEMAMPUAN MENULIS CERPEN (Studi Korelasional pada Siswa SMA Negeri 39 Jakarta)
}

\author{
Anggun Citra Dini Dwi Puspitasari \\ Program Studi Teknik Informatika, Universitas Indraprasta PGRI \\ Email: anggun.citra.dini@gmail.com
}

\begin{abstract}
Abstrak
Tujuan penelitian ini adalah untuk mengetahui apakah terdapat hubungan antara kemampuan berpikir kreatif dengan kemampuan menulis cerpen. Penelitian ini dilakukan di kelas XI SMA Negeri 39 Jakarta. Sampel dalam penelitian ini berjumlah 40 siswa. Penelitian ini menggunakan metode survei dengan teknik analisis regresi dan korelasional. Hasil dari penelitian adalah terdapat hubungan yang positif dan signifikan antara kemampuan berpikir kreatif $(\mathrm{X})$ dengan kemampuan menulis cerpen $(\mathrm{Y})$ dengan $(\mathrm{r})$ yaitu 0,902 dan persamaan regresi $\hat{Y}=20,261+0,707 X$.
\end{abstract}

Kata kunci: kemampuan, berpikir kreatif, menulis cerpen

\begin{abstract}
The objective of this research is to know whether there is any correlation between creative thinking and short story writing abilities. This research is conducted at XI grade of SMA Negeri 39 in Jakarta, with the sample consisting of 40 students. The research employs a survey method by applying regression and correlation analysis techniques. Further, the result of the research indicates that there is a positive and significant correlation between creative thinking ability $(X)$ and short story writing ability $(Y)$, as shown by the $(r)$ value of 0,902 and regression equation of $\hat{Y}=20,261+0,707 X$.
\end{abstract}

Keywords: ability, creative thinking, short story writing

\section{Pendahuluan}

Menulis merupakan keterampilan yang paling sulit dikuasai jika dibandingkan dengan aspek keterampilan bahasa yang lainnya. Sebagaimana yang diutarakan oleh Sakura Ridwan (2011: 83), kemampuan menulis merupakan kemampuan yang kompleks karena menulis mengharuskan seseorang mengerahkan segenap kemampuannya yang berupa penguatan aspek-aspek kebahasaan, isi tulisan, teknik penulisan, dan juga tentang apa yang akan ditulis serta bagaimana menyampaikannya dalam bahasa tulis.

Berdasarkan pengalaman peneliti saat melakukan Praktik Profesi Keguruan Terpadu (PPKT) di MAN 13 Jakarta, peneliti menemukan berbagai permasalahan yang kurang menyenangkan berkaitan dengan kemampuan menulis cerpen siswa, yaitu dengan ditemukannya beberapa siswa yang memiliki kemampuan menulis cerpen yang rendah, dengan nilai di bawah 70 , bahkan ada yang mendapat nilai 50. Ketika peneliti menanyakan pendapat siswa tentang kegiatan menulis cerpen, mereka berpendapat dan menganggap bahwa kegiatan menulis cerpen sebagai kegiatan yang menyulitkan, membosankan, menguras waktu dan pikiran, menuntut perhatian lebih, dan harus dilakukan dengan sungguh-sungguh. Di sini terlihat bahwa minat siswa dalam menulis cerpen sangatlah kurang.

Peneliti juga menanyakan kepada siswa tentang kesulitan-kesulitan apa saja yang mereka hadapi ketika menulis cerpen, sebagian besar siswa menjawab bahwa mereka kesulitan untuk mendapatkan ide, tema, atau topik yang akan ditulisnya. Kesulitan siswa dalam menulis cerpen tidak hanya pada pemerolehan ide dan penentuan tema. Banyak siswa yang mengalami kesulitan ketika harus menuangkan ide atau gagasannya ke dalam tulisan. Saat tema sudah didapat dan sudah ditentukan, banyak siswa yang selalu berhenti pada kalimat 
atau paragraf pertama. Proses penulisan menuntut siswa untuk lancar dalam berpikir sehingga siswa dapat mengolah kata-kata untuk memaparkan ide atau gagasannya. Menulis adalah proses penyampaian informasi secara tertulis dengan menggunakan cara berpikir yang kreatif (Dalman, 2014: 5). Oleh karena itu, agar siswa dapat menulis cerpen dengan baik, siswa harus mampu berpikir kreatif.

Di sini peneliti menduga adanya hubungan dari kemampuan berpikir kreatif dengan kemampuan menulis cerpen. Peneliti berasumsi jika semakin baik kemampuan berpikir kreatif siswa, maka semakin baik pula kemampuan menulis cerpennya. Hal ini dikarenakan kemampuan berpikir kreatif akan memudahkan siswa dalam menuangkan ide atau gagasan ke dalam bentuk cerpen. Untuk itu, pada penelitian ini, peneliti akan mencari tahu apakah memang ada hubungan kemampuan berpikir kreatif dengan kemampuan menulis cerpen pada siswa.

Berangkat dari latar belakang di atas, rumusan masalah yang peneliti rumuskan adalah apakah terdapat hubungan antara kemampuan berpikir kreatif dan kemampuan menulis cerpen siswa SMA Negeri 39 Jakarta. Sejalan dengan rumusan masalah di atas, tujuan utama penelitian ini adalah untuk mengetahui adanya hubungan antara kemampuan berpikir kreatif dengan kemampuan menulis cerpen siswa SMA Negeri 39 Jakarta.

\section{Tinjauan Pustaka \\ Menulis Cerpen}

Menulis merupakan salah satu keterampilan dalam berbahasa. Menurut Tarigan (2008: 3-4), menulis adalah suatu kegiatan produktif dan ekspresif yang diperlukan untuk berkomunikasi secara tidak langsung dengan memanfaatkan sistem tulisan, struktur bahasa, dan kosa kata. Dikatakan produktif karena kegiatan ini akan menghasilkan suatu produk berupa tulisan, sedangkan dikatakan ekspresif karena kegiatan dalam menulis berupa kegiatan menuangkan gagasan dalam bentuk tulisan.

Senada dengan pendapat Tarigan, Resmini, dkk (2007: 116) mengatakan bahwa menulis adalah suatu keterampilan berbahasa yang digunakan sebagai alat komunikasi tidak langsung untuk mencurahkan gagasan, pikiran, dan perasaan melalui media bahasa berupa tulisan. Jadi, menulis merupakan suatu keterampilan berbahasa berupa kegiatan menghasilkan suatu produk berupa tulisan untuk mencurahkan gagasan, pikiran, dan perasaan yang digunakan sebagai alat komunikasi tidak langsung dengan memanfaatkan sistem tulisan, struktur bahasa, dan kosa kata.

Salah satu jenis kegiatan menulis adalah menulis kreatif. Menulis cerpen merupakan bagian atau kegiatan dari menulis kreatif. Yunus (2015: 7) mengatakan, "menulis kreatif dapat didefinisikan sebagai proses menulis yang bertumpu pada pengembangan daya cipta dan ekspresi pribadi dalam bentuk tulisan yang baik dan menarik". Pengertian ini mengartikan bahwa menulis kreatif menekankan pada proses aktif seseorang untuk menuangkan ide dan gagasan melalui cara yang tidak biasa sehingga mampu menghasilkan karya yang berbeda, baik, dan juga menarik, seperti cerpen.

Menurut Pranoto (2004a: 6), proses menulis yang bersifat kreatif disebut penulisan kreatif (creative writing). Bersifat kreatif karena penulis harus mereka-reka sedemikan rupa dengan memasukkan imajinasi, pengalaman nyata, serta memasukkan unsur seni, khususnya seni sastra. Pranoto (2004b: 7) juga menyatakan bahwa creative writing bisa disebut sebagai pelajaran mengarang yang berarti menciptakan sebuah dunia rekaan, dunia imajiner, atau dunia yang berbeda dibandingkan dengan dunia nyata yang kita hadapi. Untuk itu, creative writing berkaitan dengan dunia yang tidak nyata, yakni fiksi (fiction). 
Namun, karya fiksi tidak seluruhnya berisi imajinasi atau khayalan belaka. Penulis karya fiksi dapat memasukan pengalaman nyata yang berupa pengalaman yang pernah terjadi pada dirinya sendiri maupun orang-orang sekitarnya. Melalui proses kreatif penulis, pengalaman yang nyata dapat dijadikan fiksi atau difiksikan. Adapun salah satu karya creative-writing adalah cerpen.

Cerpen atau cerita pendek adalah karya sastra fiksi yang pendek. Muhardi dan Hasanuddin (1992: 5) berpendapat bahwa cerpen adalah karya fiksi atau rekaan imajinatif dengan mengungkapkan satu permasalahan yang ditulis secara singkat dan padat dengan memiliki komponen-komponen atau unsur struktur berupa alur/plot, latar/setting, penokohan, sudut pandang, gaya bahasa, dan tema serta amanat. Pendapat senada juga diutarakan oleh Kosasih (2012a: 60-71) bahwa cerpen adalah karangan pendek berbentuk prosa yang dibentuk oleh beberapa komponen, yakni tema, alur, latar, penokohan, sudut pandang, amanat, dan gaya bahasa. Jadi, cerpen adalah karya fiksi berupa prosa dengan mengungkapkan satu permasalahan yang ditulis secara singkat dan padat yang dibentuk oleh beberapa komponen, yakni tema, alur, latar, penokohan, sudut pandang, amanat, dan gaya bahasa. Adapun penjabaran dari masing-masing komponen tersebut adalah sebagai berikut.

\section{Tema}

Cerpen memuat penceritaan yang hanya memusat pada satu peristiwa pokok. Satu peristiwa pokok yang menjadi pusat penceritaan ini disebut tema. Menurut Nurgiyantoro (2013a: 115), tema adalah gagasan atau makna dasar umum yang menopang sebuah karya sastra. Jadi, tema adalah suatu gagasan utama yang menjadi dasar cerita.

Gagasan atau makna utama merupakan hal yang ditawarkan penulis kepada pembaca, untuk itu tema dalam cerpen tidak disembunyikan. Namun, tema adalah makna keseluruhan yang didukung cerita-cerita, sehingga dengan sendirinya tema akan tersembunyi di balik cerita yang mendukungnya. Sumardjo dan Saini (1997: 57) mengatakan bahwa cerpen yang berhasil adalah cerpen yang berisi tema yang tersamar dalam seluruh elemen, di mana pengarang atau penulis menggunakan dialog-dialog tokoh-tokohnya, jalan pikirannya, perasaannya, kejadian-kejadian, atau latar cerita untuk mempertegas isi temanya.Untuk itu, tema dapat dinilai berdasarkan kualitas tema, kejelasan dan keterlihatannya di dalam keseluruhan cerita.

\section{Alur}

Tema memang merupakan dasarnya cerita.Namun, untuk dapat menjadi sebuah cerpen, tema dikembangkan oleh plot/alur. Kosasih (2012b: 63) mengatakan bahwa alur adalah pola pengembangan cerita yang terbentuk oleh hubungan sebab-akibat.Pendapat senada diutarakan oleh Nurgiyantoro (2013b: 168) yang mengatakan bahwa alur adalah peristiwaperistiwa yang diseleksi dan diurutkan berdasarkan hubungan sebab-akibat untuk mencapai efek tertentu sekaligus membangkitkan ketegangan dan kejutan pada pembaca.Untuk itu, hendaknya alur disusun berdasarkan hubungan sebab-akibat agar tercapai suatu efek yang membangkitkan ketegangan dan kejutan pada pembaca.

Menurut Stanton (2012: 28), alur merupakan tulang punggung cerita, sebab sebuah cerita tidak akan pernah seutuhnya dimengerti tanpa adanya pemahaman terhadap peristiwaperistiwa yang saling berkait, berhubungan kausalitas, dan saling berpengaruh, selain itu alur hendaknya memiliki bagian awal, tengah, dan akhir yang nyata, meyakinkan dan logis, dapat menciptakan bermacam kejutan, dan memunculkan sekaligus mengakhiri keteganganketegangan. Dengan demikian, dapat dikatakan bahwa alur merupakan unsur yang sangat penting dalam cerpen karena alur mengatur bagaimana tindakan-tindakan harus bertalian satu sama lain, bagaimana satu peristiwa mempunyai hubungan dengan peristiwa lain, serta 
bagaimana tokoh digambarkan dan berperan dalam peristiwa yang semuanya terikat dalam suatu kesatuan.

Semi (1988a: 46) menyatakan bahwa baik-tidaknya sebuah alur ditentukan oleh hal-hal berikut, yakni (a) apakah tiap peristiwa susul-menyusul secara logis dan alamiah; (b) apakah tiap peristiwa sudah cukup tergambar atau dimatangkan dalam peristiwa sebelumnya; dan (c) apakah peristiwa itu terjadi secara kebetulan atau dengan alasan yang masuk akal atau dapat dipahami kehadirannya. Jadi menurut Semi, alur yang baik adalah alur yang dibentuk dari rangkaian peristiwa yang tersusun secara logis dan alamiah, setiap peristiwa tergambar dan dimatangkan dalam peristiwa sebelumnya atau hubungan sebab-akibat, kemudian peristiwa tersebut dapat dipahami kehadirannya.

Sementara itu Klarer (2004: 15) mengatakan bahwa alur dapat diurutkan berdasarkan empat tingkatan, yaitu pengenalan situasi cerita (exposition), pengungkapan peristiwa (complication), klimaks (climax) atau puncak konflik (turning point), dan penyelesaian (ending) atau resolution. Urutan alur ini menjelaskan bahwa kekuatan sebuah cerita terdapat bagaimana seorang penulis membawa pembacanya mengikuti timbulnya konflik, memuncaknya konflik, dan berakhirnya konflik. Timbulnya konflik atau terbinanya alur sering berhubungan erat dengan unsur penokohan atau tema, bahkan juga latar. Berdasarkan beberapa teori di atas, dapat disimpulkan bahwa alur dapat dinilai dari bagaimana alur itu diciptakan dari tahap perkenalan, pemunculan konflik, klimaks, hingga penyelesaian, dengan adanya urutan peristiwa yang berhubungan sebab-akibat dan logis.

\section{Latar}

Alur berperan mengatur jalannya cerita, namun untuk memperkuat dan mempertegas jalannya cerita diperlukanlah latar. Muhardi dan Hasanudin (1992b: 30) mengatakan bahwa latar bertujuan untuk memperjelas suasana, tempat, dan waktu peristiwa yang terjadi di dalam cerita. Untuk itu, dengan jelasnya suasana, tempat, dan waktu yang terjadi di dalam cerita, maka akan memperkuat dan mempertegas jalannya cerita. Latar dalam suatu cerpen bisa bersifat faktual atau bisa juga bersifat imajiner. Keberhasilan suatu latar ditentukan dari kesesuaian dan ketergambaran dengan jelas tempat, waktu, dan suasana dalam membangun cerita sehingga kesan di mana, kapan, dan bagaimana situasi terjadi dapat terlihat dengan baik.

\section{Tokoh dan Penokohan}

Dalam sebuah cepen, tentunya ada sesuatu yang berperan dan bagaimana sesuatu tersebut diperankan, ini disebut tokoh dan penokohan. Menurut Ahmad (1994: 65), tokoh adalah individu rekaan yang memegang peranan dalam cerpen, sedangkan penokohan adalah sifat dan ciri yang terdapat pada tokoh, kualitas pikiran dan jiwa yang membedakan dengan tokoh lain. Sementara itu, Aziez dan Hasim (2010a: 47) mengatakan bahwa tokoh merupakan pelaku yang menjalankan peristiwa dalam cerita sehingga peristiwa itu mampu menjalin cerita, adapun penokohan merupakan cara penulis menampilkan tokoh atau pelaku dalam cerita. Jadi, dapat disimpulkan bahwa tokoh adalah pelaku atau pemeran di dalam cerita, sedangkan penokohan adalah bagaimana para pelaku berperilaku di dalam cerita.

Pada dasarnya, penokohan merupakan cara penulis menggambarkan dan menggembangkan karakter tokoh-tokoh dalam cerita. Menurut Kosasih (2012c: 68), untuk dapat menggambarkan karakter seorang tokoh, penulis dapat menggunakan teknik analitik dan teknik dramatik. Teknik analitik yaitu teknik yang digunakan untuk menceritakan karakter tokoh secara langsung, sedangkan teknik dramatik yaitu teknik yang digunakan untuk menceritakan karakter tokoh secara tidak langsung, bisa melalui penggambaran fisik dan perilaku tokoh, penggambaran lingkungan kehidupan tokoh, penggambaran tata kebahasaan tokoh, pengungkapan jalan pikiran tokoh, dan penggambaran oleh tokoh lain. Keberhasilan 
suatu tokoh dan penokohan ditentukan dari penggambaran watak tokoh, apakah terlihat nyata atau hidup, sehingga tokoh mampu membawa pembaca seolah-olah mengalami kejadian dalam cerita.

\section{Sudut Pandang}

Pada dasarnya sebuah cerita dituturkan oleh penulisnya. Namun, penulis dapat menggunakan tokoh dalam cerita untuk menuturkan kejadian-kejadian pada cerita tersebut. Selain itu, penulis dapat memposisikan diri dan berperan sebagai tokoh dalam cerita atau hanya sebagai narator saja. Menurut Semi (1988b: 57), posisi dan penempatan diri penulis dalam ceritanya serta dari mana ia melihat peristiwa-peristiwa yang terdapat dalam ceritanya itu disebut sudut pandang. Dari sudut pandang inilah pembaca mengikuti jalannya cerita dan memahami temanya.

Pemilihan posisi dalam membawakan cerita pada hakikatnya juga merupakan teknik bercerita agar apa yang dikemukakan atau apa yang dikisahkan menjadi lebih efektif. Kosasih (2012d: 69-70) mengatakan bahwa posisi penulis dalam membawakan cerita terdiri atas dua macam, yaitu (a) berperan langsung sebagai orang pertama atau sebagai tokoh, baik tokoh utama maupun tokoh pembantu yang terlihat dalam cerita, di sini penulis memakai istilah aku atau saya; (b) berperan sebagai orang ketiga atau sebagai pengamat, di sini penulis hanya menceritakan apa yang terjadi di antara tokoh-tokoh cerita yang ditulisnya dan biasanya penulis memakai kata ia, dia, atau memakai nama orang.Jadi, posisi penulis dalam membawakan cerita ada yang berperan langsung di dalam cerita dan ada pula yang hanya sebagai pengamat.

Sudut pandang dalam suatu cerpen haruslah konsisten. Keberhasilan suatu sudut pandang ditentukan dari pemilihan sudut pandang yang tepat dan konsisten, sehingga pembaca dapat mengikuti jalannya cerita dan memahami temanya.

\section{Amanat}

Menurut Aziez dan Hasim (2010b: 64), amanat adalah pesan yang ingin disampaikan penulis kepada pembaca melalui ceritanya. Pendapat senada diutarakan oleh Kosasih (2012e: 71) yang mengatakan bahwa amanat adalah ajaran moral atau pesan didaktis yang hendak disampikan penulis kepada pembaca melalui karyanya. Dapat disimpulkan bahwa amanat merupakan pesan yang terkandung dalam cerita atau pesan didaktis yang hendak disampaikan penulis kepada pembaca melalui ceritanya tersebut.

Cerpen yang baik adalah cerpen yang mengandung pesan moral di dalamnya. Meskipun cerpen itu berisi cerita tentang kehidupan pelacuran, perdukunan, atau pergaulan bebas remaja, namun dalam cerpen tersebut haruslah mengandung pesan moral untuk pembaca. Biasanya amanat pada cerpen tidak langsung terlihat karena amanat disajikan penulis secara tersirat di dalam keseluruhan isi cerita. Oleh karena itu, keberhasilan suatu amanat ditentukan dari pemuatan dan penyampaian pesan moral yang mendidik.

\section{Gaya Bahasa}

Menurut Keraf (2005: 113), gaya bahasa adalah cara mengungkapkan pikiran melalui bahasa secara khas yang memperlihatkan jiwa dan kepribadian penulis sebagai pemakai bahasa. Untuk itu, gaya seorang penulis dalam menggunakan bahasa tidak sama dengan penulis lain. Sementara itu, Muhardi dan Hasanuddin (1992c: 35) mengatakan bahwa gaya bahasa menyangkut kemahiran penulis menggunakan bahasa sebagai medium fiksi. Kemahiran penulis menggunakan bahasa sangatlah penting, sebab seluruh unsur tadi yaitu tema, alur, latar, tokoh, sudut pandang, dan amanat dapat terealisasikan menjadi sebuah cerpen melalui bahasa. 
Kemampuan penulis dalam menggunakan bahasa berfungsi untuk membuat cerpen menjadi lebih hidup dan menarik. Cerpen yang baik adalah cerpen yang dapat mengajak pembaca untuk turut serta merasakan kejadian pada setiap peristiwa yang diceritakan, seakan pembaca masuk ke dalam peristiwa, dan merasakan bagaimana gejolak batin yang dirasakan tokoh. Untuk itu, keberhasilan suatu gaya bahasa ditentukan dari penggunaan diksi dan gaya bahasa yang bervariasi dan ekspresif.

Berdasarkan uraian di atas, dapat disimpulkan bahwa kemampuan menulis cerpen adalah kapasitas individu untuk dapat menuangkan ide atau gagasan, pengalaman, perasaan, serta imajinasinya ke dalam bentuk prosa fiksi yang pendek dan padat dengan hanya memuat satu peristiwa pokok yang di dalamnya terdapat unsur-unsur struktur cerpen. Unsur-unsur struktur cerpen tersebut meliputi tema, alur, latar, penokohan, sudut pandang, amanat, dan gaya bahasa.

\section{Berpikir Kreatif}

Berpikir menurut Santrock (2006a: 287), berarti memanipulasi atau mengelola dan mentransformasi informasi dalam ingatan. Sependapat dengan Santrock, Purwanto (2007: 43) mengatakan bahwa berpikir berarti mengelola berbagai pengalaman dan tanggapan yang diambil dari segala sesuatu yang pernah dialami dan disimpan dalam ingatan.Jadi, berpikir merupakan kegiatan mengelola dan mentransformasi informasi, pengalaman, serta tanggapan yang diambil dari segala sesuatu yang pernah dialami dan disimpan dalam ingatan.

Ambarjaya (2012a: 35) mengatakan bahwa makna kata kreatif berkisar pada persoalan menghasilkan sesuatu yang inovatif berupa ide atau gagasan yang diperoleh dari proses berpikir. Dengan demikian, berpikir kreatif merupakan kegiatan mengelola dan mentransformasi informasi dalam ingatan hingga membentuk suatu konsep, ide, atau gagasan yang inovatif.

Sementara itu, Kaufman dan Sternberg (2010: 467) mendefinisikan kreativitas ke dalam dua aspek. Aspek pertama yaitu hal yang baru berupa karya kreatif yang orisinal atau asli dan khas, lalu aspek kedua yaitu kualitas atau daya guna. Dengan begitu, kreativitas tidak hanya menghasilkan karya baru atau inovatif, tetapi juga sesuatu yang baik, atau bahkan berguna.

Jamaris (2010: 98) telah merumuskan beberapa karakteristik kemampuan berpikir kreatif, yaitu kelancaran, kelenturan, keaslian, dan elaborasi. Kelancaran berarti kemampuan individu dalam memberikan jawaban dan mengemukakan pendapat, gagasan, atau ide-ide secara lancar. Kelenturan berarti kemampuan individu untuk mengemukakan berbagai alternatif dalam memecahkan masalah. Keaslian berarti kemampuan individu untuk menghasilkan berbagai ide atau karya yang asli dari hasil pemikiran sendiri. Elaborasi berarti kemampuan individu dalam memperluas ide dan aspek-aspek yang mungkin tidak terpikirkan atau terlihat oleh orang lain.

Pendapat senada juga diutarakan oleh Munandar (2012: 43) bahwa terdapat empat kriteria atau karakteristik dari berpikir kreatif, yaitu kelancaran, kelenturan, keaslian (orisinalitas), dan kerincian (elaborasi). Kelancaran dalam berpikir berarti kemampuan menjawab dan mengemukakan pendapat, gagasan, atau ide-ide dengan cepat dan tepat. Seseorang dengan kefasihan ideasional (ideational fluency )yang tinggi dapat menghasilkan banyak gagasan dan ide yang relevan dengan persoalan dalam waktu yang singkat. Kelenturan dalam berpikir berarti kemampuan memberikan gagasan dan ide-ide yang beragam.Keaslian dalam berpikir berarti kemampuan memberikan gagasan yang unik, inovatif, dan asli dari hasil pemikiran sendiri dan kemampuan melihat hubungan-hubungan baru, atau kombinasi baru dari bermacam elemen. Kerincian dalam berpikir berarti kemampuan mengembangkan, memperinci, dan memperkaya atau memperluas gagasan yang tidak terpikirkan orang lain. 
Sementara itu, Buzan (2007: 98) mengatakan bahwa yang termasuk kemampuan berpikir kreatif, yaitu kefasihan, fleksibilitas, dan orisinal. Kefasihan berarti seberapa cepat dan seberapa mudah seseorang melepaskan ide-ide baru yang kreatif. Fleksibilitas berarti kemampuan melihat dan mempertimbangkan sesuatu dari sudut pandang lain dan berlawanan, mengambil konsep-konsep lama dan mengatur serta menggunakannya kembali dalam cara baru, dan membalikkan ide-ide yang sudah ada. Orisinalitas berarti kemampuan menghasilkan ide-ide yang unik, tidak biasa, aneh, atau tidak wajar.

Pada dasarnya, para pakar di atas membahas masalah karakteristik kemampuan berpikir kreatif yang sama, di mana secara umum karakteristik kemampuan berpikir kreatif, meliputi kelancaran (kefasihan), kelenturan (fleksibilitas), keaslian (orisinalitas), dan kerincian (elaborasi). Untuk itu, dapat disimpulkan bahwa karakteristik kemampuan berpikir kreatif adalah kelancaran (kefasihan), kelenturan (fleksibilitas), keaslian (orisinalitas), dan kerincian (elaborasi).

\section{Metodologi Penelitian}

Penelitian ini menggunakan metode survei dengan teknik analisis regresi dan korelasional. Pendekatan penelitian ini bersifat kuantitatif karena data yang dikumpulkan merupakan data kuantitatif berupa skor variabel yang diteliti.

Penelitian dilakukan di SMA Negeri 39 Jakarta dengan populasi penelitian adalah seluruh siswa kelas XI SMA Negeri 39 Jakarta tahun pelajaran 2014/2015 dengan jumlah 353 siswa. Sampel penelitian diambil dengan menggunakan teknik sampling acak sederhana (simple random sampling) dan ditetapkan jumlah sampel sebanyak 40 siswa.

Sesuai dengan masalah dan tujuan penelitian, data penelitian yang diperlukan dalam penelitian ini adalah data mengenai kemampuan berpikir kreatif $(\mathrm{X})$ dan data kemampuan menulis cerpen $(\mathrm{Y})$. Kedua data tersebut dikumpulkan dengan menggunakan tes produk.

Setelah data penelitian dikumpulkan dalam bentuk skor, kemudian data-data tersebut dianalisis. Teknik analisis data yang digunakan untuk menganalisis meliputi analisis data dengan statistika deskriptif dan analisis data dengan statistika inferensial. Analisis data dengan statistika deskriptif terdiri atas penyajian data dengan penghitungan mean, median, modus, standar deviasi, varian, dan rentang skor atau range.

Analisis data dengan statistika inferensial digunakan untuk melakukan pengujian hipotesis. Namun, sebelum melakukan pengujian hipotesis, langkah yang harus dilalui terlebih dahulu adalah menguji normalitas dan homogenitas sebagai persyaratan analisis. Uji normalitas dilakukan untuk menguji apakah populasi berdistribusi normal atau tidak. Pengujian normalitas ini dilakukan dengan menggunakan rumus uji Liliefors. Adapun uji homogenitas dilakukan untuk mengetahui homogenitas varians antara kelompok-kelompok skor variabel terikat (Y) yang dikelompokkan berdasarkan kesamaan nilai variabel bebas (X). Pengujian homogenitas dilakukan dengan uji Bartlett.

Setelah pengujian normalitas dan homogenitas, barulah dilakukan pengujian hipotesis. Hipotesis yang diuji dalam penelitian ini adalah "terdapat hubungan positif antara kemampuan berpikir kreatif dan kemampuan menulis cerpen" dengan menggunakan teknik regresi linear sederhana dan teknik korelasi sederhana yakni Pearson Product Moment.

\section{Hasil dan Pembahasan}

\section{Hasil Penelitian}

Hasil analisis statistika deskriptif variabel kemampuan menulis cerpen (Y) dan kemampuan berpikir kreatif $(\mathrm{X})$ dapat dilihat pada tabel berikut: 
Tabel 1. Deskripsi Data

\begin{tabular}{lcc}
\hline Sebaran Data & $\begin{array}{c}\text { Kemampuan Menulis } \\
\text { Cerpen }\end{array}$ & $\begin{array}{c}\text { Kemampuan Berpikir } \\
\text { Kreatif }\end{array}$ \\
\hline Sampel & 40 & 40 \\
Jumlah & 2870,00 & 2915,00 \\
Mean & 71,7500 & 72,8750 \\
Median & 70,7500 & 73,7500 \\
Modus & 60,00 & 65,00 \\
Std. Deviasi & 10,98367 & 14,02322 \\
Varians & 120,641 & 196,651 \\
Range & 35,50 & 52,50 \\
Minimum & 54,50 & 42,50 \\
Maximum & 90,00 & 95,00 \\
\hline
\end{tabular}

Hasil uji normalitas kemampuan menulis cerpen (Y) diperoleh nilai $\mathrm{L}_{0}=0,1204$ dan uji normalitas kemampuan berpikir kreatif $(\mathrm{X})$ diperoleh nilai $\mathrm{L}_{0}=0,1128$. Kedua nilai tersebut lebih kecil dari $\mathrm{L}_{\mathrm{t}}=0,1419$. Oleh karena $\mathrm{L}_{0}(0,1204$ dan 0,1128$)<\mathrm{L}_{\mathrm{t}}(0,1419)$, maka data $\mathrm{Y}$ dan data $\mathrm{X}$ berasal dari populasi yang berdistribusi normal.Untuk uji homogenitas, penghitungan pengujian homogenitas varians $\mathrm{Y}$ atas $\mathrm{X}$ diperoleh $\chi_{\text {hitung }}^{2}=12,303$. Nilai $\chi_{\text {tabel }}^{2}$ dengan dk 15 pada $\alpha=0,005$ sebesar 24,996 dan pada $\alpha=0,01$ sebesar 30,578. Oleh karena $\chi_{\text {hitung }}^{2}(12,303)<\chi_{\text {tabel }}^{2}\left(24,996\right.$ dan 30,578), maka $\mathrm{H}_{0}$ diterima, artinya varians kelompok-kelompok $\mathrm{Y}$ atas $\mathrm{X}$ adalah homogen.

Setelah diketahui bahwa data berasal dari populasi yang berdistribusi normal dan homogen, maka langkah selanjutnya adalah melakukan pengujian hipotesis. Hasil penghitungan hipotesis diperoleh model persamaan regresi $\hat{Y}=20,261+0,707 X$, koefisien korelasi $(r)=$ 0,902 , koefisien determinasi $(r)^{2}=0,8136$.

\section{Pembahasan}

Beberapa pembahasan dan interpretasi hasil penelitian di atas, dikemukakan lebih mendalam pada uraian di bawah ini. Hasil pengujian hipotesis menyatakan bahwa terdapat hubungan positif dan signifikan antara kemampuan berpikir kreatif $(X)$ dan kemampuan menulis cerpen $(\mathrm{Y})$. Hal ini dibuktikan dengan nilai koefisien korelasi pada persamaan linear sederhana $\hat{Y}=20,261+0,707 X$ yang mengartikan bahwa apabila kemampuan berpikir kreatif siswa kelas XI SMA Negeri 39 Jakarta sama dengan nol (tidak ada perubahan), maka kemampuan menulis cerpennya sebesar 20,261 dan apabila kemampuan berpikir kreatif siswa kelas XI SMA Negeri 39 Jakarta meningkat sebesar 1 satuan, maka kemampuan menulis cerpennya akan meningkat sebesar 0,707. Nilai koefisien korelasi $(r)=0,902$ dan koefisien determinasi $(\mathrm{r})^{2}=0,8136$ yang menunjukkan bahwa $81,36 \%$ dari kemampuan menulis cerpen siswa kelas XI SMA Negeri 39 Jakarta dipengaruhi oleh kemampuan berpikir kreatifnya. Hal ini memperlihatkan bahwa kemampuan berpikir kreatif memiliki hubungan langsung dengan kemampuan menulis cerpen.

Adanya hubungan antara kemampuan berpikir kreatif dan kemampuan menulis cerpen pada siswa kelas XI SMA Negeri 39 Jakarta ini tampak pada perolehan skor kemampuan berpikir kreatif yang tinggi dibarengi dengan perolehan skor kemampuan menulis cerpen yang tinggi pula dan perolehan skor kemampuan berpikir kreatif yang rendah dibarengi dengan perolehan skor kemampuan menulis cerpen yang rendah pula. Siswa yang memperoleh skor tertinggi pada variabel kemampuan berpikir kreatif dengan nilai 95, memperoleh skor tertinggi pula pada variabel kemampuan menulis cerpen dengan nilai 90, dan siswa yang memperoleh skor terendah pada variabel kemampuan berpikir kreatif dengan nilai 42,5, memperoleh skor yang rendah pula pada variabel kemampuan menulis cerpen dengan nilai 55. Dapat ditarik kesimpulan bahwa semakin tinggi kemampuan berpikir kreatif siswa, maka semakin tinggi pula kemampuan menulis cerpennya. Begitu pula sebaliknya, semakin rendah 
kemampuan berpikir kreatif siswa, maka semakin rendah pula kemampuan menulis cerpennya. Sehingga, dengan meningkatkan unsur kemampuan berpikir kreatif, maka akan dapat meningkatkan kemampuan menulis cerpen siswa.

Menurut Dalman (2014b: 5), menulis adalah proses penyampaian informasi secara tertulis dengan menggunakan cara berpikir yang kreatif. Muhardi dan Hasanuddin (1992d: 5) berpendapat bahwa cerpen adalah karya fiksi atau rekaan imajinatif dengan mengungkapkan satu permasalahan yang ditulis secara singkat dan padat dengan memiliki komoponenkomponen atau unsur struktur berupa alur/plot, latar/setting, penokohan, sudut pandang, gaya bahasa, dan tema serta amanat. Menulis cerpen pada dasarnya merupakan kegiatan menuangkan ide atau gagasan, pengalaman, perasaan, serta imajinasi ke dalam bentuk tulisan berupa prosa fiksi yang pendek. Kegiatan menulis cerpen mengharuskan siswa menggunakan daya imajinasi secara maksimal ketika mengembangkan tulisan, mulai dari mengembangkan tema, merangkaikan peristiwa, menggambarkan karakter tokoh, dan melukiskan latar. Untuk itu, agar siswa dapat menulis cerpen dengan baik, siswa harus memikirkan dan mengolah informasi, ide, gagasan, perasaan, serta imajinasinya, dan menghubungkan satu konsep dengan konsep lain. Seluruh rangkaian kegiatan dalam menulis cerpen tersebut tidak lepas dari kegiatan berpikir kreatif.

Berpikir menurut Santrock (2006b: 287), berarti memanipulasi atau mengelola dan mentransformasi informasi dalam ingatan. Sementara itu, Ambarjaya (2012b: 35) mengatakan bahwa makna kata kreatif berkisar pada persoalan menghasilkan sesuatu yang inovatif berupa ide atau gagasan yang diperoleh dari proses berpikir. Dengan demikian, berpikir kreatif merupakan kegiatan mengelola dan mentransformasi informasi dalam ingatan hingga membentuk suatu konsep, ide, atau gagasan yang inovatif. Siswa yang kemampuan berpikir kreatifnya tinggi dapat mengelola dan mentransformasi informasi, ide, gagasan, perasaan, serta imajinasinya ke dalam tulisan berupa cerpen, sehingga kemampuan menulisnya pun tinggi. Siswa tersebut mampu mengembangkan tulisan dan menggunakan daya imajinasinya, mulai dari mengembangkan tema, merangkaikan peristiwa, menggambarkan karakter tokoh, dan melukiskan latar. Dengan kata lain, ia mampu menulis cerpen dengan baik. Inilah yang memperlihatkan adanya hubungan kemampuan berpikir kreatif dengan kemampuan menulis cerpen.

\section{Simpulan dan Saran \\ Simpulan}

Berdasarkan kerangka teoretik dan temuan penelitian, maka kesimpulan dalam penelitian ini adalah terdapat hubungan positif dan signifikan antara kemampuan berpikir kreatif dengan kemampuan menulis cerpen. Hubungan positif antara kemampuan berpikir kreatif dengan kemampuan menulis cerpen yang ditunjukkan dalam temuan penelitian ini, menunjukkan bahwa kemampuan menulis cerpen tidak akan muncul dengan sendirinya, melainkan ditentukan oleh beberapa faktor yang di antaranya adalah kemampuan berpikir kreatif.

\section{Saran}

Dari kesimpulan tersebut, peneliti memberikan saran, apabila ingin meningkatkan kemampuan menulis cerpen siswa, maka siswa dapat diupayakan melalui peningkatan kemampuan berpikir kreatif.

\section{Daftar Pustaka}

Ahmad, Shahnon. (1994). Sastera; Pengalaman Ilmu Imaginasi dan Kitarannya. Kuala Lumpur: Dewan Bahasa dan Pustaka Kementerian Pendidikan Malaysia.

Ambarjaya, B. S. (2012). Psikologi Pendidikan dan Pengajaran: Teori dan Praktik. Yogyakarta: CAPS. 
Aziez, Furqonul dan Hasim, Abdul. (2010). Menganalisis Fiksi sebuah Pengantar. Jakarta: Multikreasi Satudelapan.

Buzan, Tony. (2007). Buku Pintar Mind Map. Jakarta: PT Gramedia.

Dalman. (2014). Keterampilan Menulis. Jakarta: Rajawali Press.

Jamaris, Martini. (2010). Orientasi Baru dalam Psikologi Pendidikan. Jakarta: Yayasan Penamas Murni.

Kaufman, J. C. dan Sternberg, R. J. (2010). Creativity, ed. Cambridge: Cambridge University Press.

Keraf, Gorys. (2005). Diksi dan Gaya Bahasa. Jakarta: PT Gramedia Pustaka Utama.

Klarer, Mario. (2004). An Introduction to Literary Studies. London: Routledge,

Kosasih, E. (2012). Dasar-dasar Keterampilan Bersastra. Bandung: Yrama Widya.

Muhardi dan Hasanuddin. (1992). Prosedur Analisis Fiksi. Padang: IKIP Padang Press.

Munandar, Utami. (2012). Pengembangan Kreativitas Anak Berbakat. Jakarta: PT Rineka Cipta.

Nurgiyantoro, Burhan. (2013). Teori Pengkajian Fiksi. Yogyakarta: Gajah Mada University Press.

Pranoto, Naning. (2004). Creative Writing. Jakarta: PT Primamedia Pustaka.

Purwanto, Ngalim. (2007). Psikologi Pendidikan. Bandung: PT Remaja Rosdakarya.

Resmini, Novi dan Dadan Juanda. (2007). Pendidikan Bahasa dan Sastra Indoesia di Kelas Tinggi. Bandung: UPI Press.

Ridwan, Sakura. (2011). Metodologi Pembelajaran Bahasa: Aplikasi dalam Pengajaran Morfologi-Sintaksis. Yogyakarta: Kepel Press.

Santrock, J. W. (2006). Educational Psychology. New York: McGraw-Hill.

Semi, M. A. (1988). Anatomi Sastra. Padang: Angkasa Raya.

Stanton, Robert. (2012). Teori Fiksi Robert Stanton terjemahan Sugihastuti dan Rossi Abi Al Irsyad. Yogyakarta: Pustaka Pelajar.

Sumardjo, Jakob dan Saini K.M. (1997). Apresiasi Kesusastraan. Jakarta: PT Gramedia Pustaka Utama.

Tarigan, H. G. (2008). Menulis sebagai Suatu Keterampilan Berbahasa. Bandung: Angkasa Bandung.

Yunus, Syarifudin. (2015). Kompetensi Menulis Kreatif. Bogor: Ghalia Indonesia. 